\title{
Change in size-at-maturity of the yellownose skate Dipturus chilensis (Guichenot, 1848) (Elasmobranchii: Rajidae) in the SW Atlantic
}

\author{
Laura Paesch $^{1}$ and María C. Oddone ${ }^{2}$
}

A total of 3518 specimens (1607 males, 1911 females) of Dipturus chilensis were sampled. Males ranged from 44.0 to $99.0 \mathrm{~cm}$ and females from 45.0 to $110.0 \mathrm{~cm}$. Total length composition of the grouped catches differed significantly among sexes, with females being larger than males. The sex ratio favored the females. The total length at which $50 \%$ of the specimens were retained by the gear was $69.0 \mathrm{~cm}$ for the males and $73.0 \mathrm{~cm}$ for the females. A sub-sample of 124 specimens (48 males, 76 females) was analyzed for reproductive assessment. For the males, size at $50 \%$ maturity was estimated at $78.5 \mathrm{~cm}$, while for the females this parameter was estimated at $81.4 \mathrm{~cm}$. Preliminary observations on the description of the egg capsules are also provided.

Um total de 3518 espécimes (1607 machos e 1911 fêmeas) de Dipturus chilensis foi amostrado. Os machos tiveram comprimentos totais entre 44.0 e $99.0 \mathrm{~cm}$ e as fêmeas entre 45.0 e $110.0 \mathrm{~cm}$. A composição de comprimentos totais das capturas agrupadas foi significativamente diferente entre ambos os sexos, sendo as fêmeas maiores do que os machos. A razão sexual favoreceu as fêmeas. O comprimento total em que 50\% dos espécimes foram retidos pelo aparelho de pesca foi de $69.0 \mathrm{~cm}$ nos machos e de 73.0 cm nas fêmeas. Uma sub-amostra de 124 espécimes (48 machos e 76 fêmeas) foi analisada para avaliação dos parâmetros reprodutivos. Para os machos, o tamanho de $50 \%$ de maturidade resultou em $78.5 \mathrm{~cm}$ enquanto que para as fêmeas este parâmetro foi estimado em 81.4 cm. Observações preliminares sobre a descrição da cápsula ovígera são também fornecidas.

Key words: Clasper, Fishery-dependent samples, Rajid, Reproduction, Size composition.

\section{Introduction}

Longnosed skates (genus Dipturus Rafinesque, 1810) include about 31 species (with several questionably placed in the genus) and are virtually circumglobal in cool-water to tropical seas, demersal on shelves and slopes (Compagno, 2005). Dipturus chilensis (Guichenot, 1848) ranges from Uruguay (Southwestern Atlantic) to central Chile (Southeastern Pacific), where they are distributed around southern South America (Menni \& Gosztonyi, 1982; Menni \& López, 1984; Lucifora et al., 2000).

In Chilean waters, $D$. chilensis specimens were formerly taken as by-catch in the bottom longline fishery that targeted Chilean hakes (Merluccius gayi and Merluccius australis) and kingclip (Genypterus blacodes). However, in the last decade, they have increased in commercial value due to the opening of the Asian market (e.g., Korea), being now a target species in the fisheries of southern Chile, which has led to increased landings that reached a maximum peak of $7000 \mathrm{t}$ in 2001 (Licandeo et al., 2006).
In Uruguay, $D$. chilensis is not only caught as by-catch in bottom-trawling commercial fisheries but also targeted by two Uruguayan longline vessels, along with Sympterygia bonapartii.

So far, it is well known that the life history trends of rajids, such as slow growing, low fecundity and late maturity, make them extremely susceptible to fishing pressure (Hoenig \& Gruber, 1990; Walker \& Heensen, 1996), but resilience to fishing pressure seems to vary among skate species (Frisk et al., 2002). To date, the conservational status of $D$. chilensis is unknown; and this is a matter of concern for a species subjected to fishing pressure.

Knowledge of reproductive parameters such as size-atmaturity is of special interest for fisheries management, where it is widely used as an indicator of the minimum permissible size at capture (Caddy \& Mahon, 1996; Lucifora et al., 1999). Moreover, it allows establishing the basis for later estimations, should changes in size-at-maturity be due to fishing pressure or other reasons such as geographical latitude (Templeman, 1987). Natural stocks of fish respond differently

${ }^{1}$ Dirección Nacional de Recursos Acuáticos (DINARA), Departamento de Biología Pesquera, Constituyente 1497, Cx. P: 11200-P. O. Box 1612, Montevideo, 11200, Uruguay. lpaesch@dinara.gub.uy

${ }^{2}$ Universidade Estadual Paulista, Departamento de Ecologia, Campus Rio Claro Av. 24-A 1515, Cx. P: 199, $13506-900$ Rio Claro, SP, Brazil. 
to fishing pressure which somewhat erodes natural genetic diversity in order to select the genotypes that are better able to withstand the impacts, and the change in size-at-maturity is one of the more worrisome genetic changes (Walters \& Martell, 2004).

Egg capsule's morphology as well as clasper's cartilaginous structure in the males are species-specific and can aid in species identification, being commonly used as a taxonomic tool for species identification (Ishiyama, 1958). So far, there is no record of the egg capsule of $D$. chilensis in the literature for the study area.

The aim of this work was to present a new estimation of size-at-maturity for $D$. chilensis and to compare it with a previous estimation of Oddone et al. (2005) for the same area, the Southwestern Atlantic Ocean, made one decade prior. In order to determine length at $50 \%$ of the individuals were retained in the gear, the size composition of the catch for this species was also analyzed. Given that there are no bibliographic references on the egg capsule of $D$. chilensis, a description is provided.

\section{Material and Methods}

Sampling. Specimens were collected during nine cruises carried out from March to October of 2004. The samples of skates were landed by four trawling vessels of the Uruguayan commercial fleet, operating between latitudes $37^{\circ} 00^{\prime}$ and $39^{\circ} 30^{\prime} \mathrm{S}$ and at 75 to $200 \mathrm{~m}$ deep (Fig. 1). Codend mesh size used was $120 \mathrm{~mm}$.

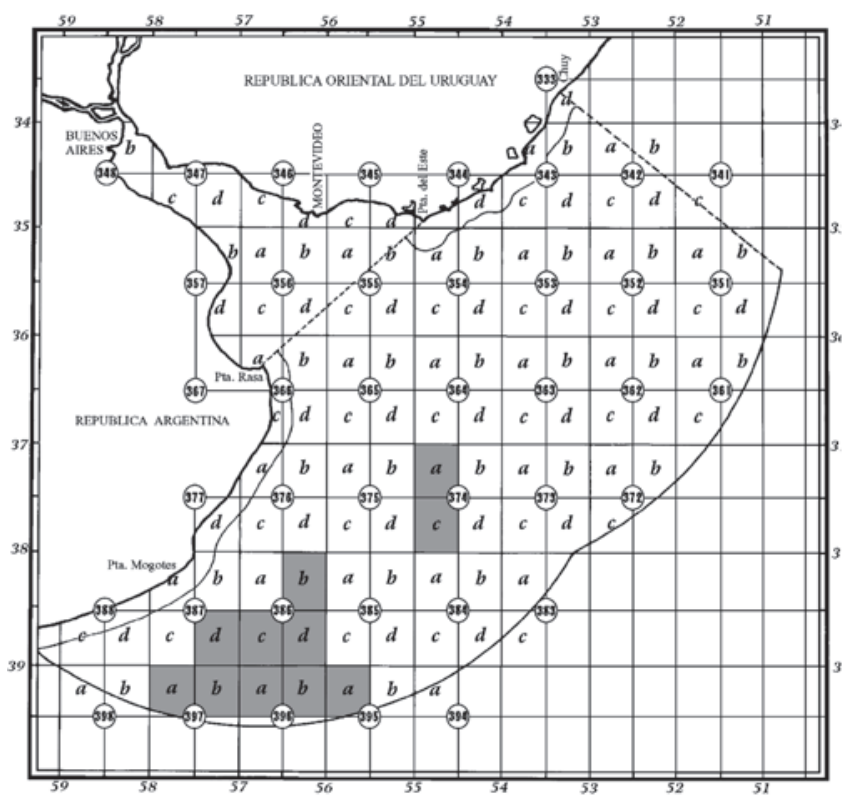

Fig. 1. Map of the study area; the Argentinean-Uruguayan Common Fishing Zone, Southwestern Atlantic Ocean. Shaded squares represent the operative fishing areas (each one consisting of sub-areas a, b, c and d) from where samples of Dipturus chilensis were obtained.
Size and sex composition of the catch. Sex and total length (TL) of the specimens to the nearest $\mathrm{cm}$ below were recorded and the relative and cumulative frequency of TL by sex was calculated. Differences between the length composition of landed catches by sex were tested using the Mann-Whitney test (Sokal \& Rohlf, 1998). The equality of the proportion of males/females in the samples was tested using the $\chi^{2}$ test (Sokal \& Rohlf, op. cit.). Significance level used in the tests was 0.05 .

Maturity assessment. A random sub-sample of specimens (with number of individuals varying per landed catches) was collected for analysis of reproductive characteristics. In the males, the variables considered to assess maturity were clasper length, measured from the point of insertion to the distal end sensu Compagno (1984), and the appearance of reproductive ducts and presence of alar thorns. Clasper length as independent variable of the TL was analyzed. In the females, maturity was estimated by the analysis of the macroscopical appearance of the reproductive ducts, i.e., presence/absence of vitellogenic follicles and/or egg capsules in the ovaries and uteri, respectively, and nidamental gland, in relation to TL.

Three stages were assumed to characterize the degree of maturity in males: 1) Immature: flexible, non-calcified claspers, with length shorter than pelvic fin length; straight, filiform sperm ducts, alar thorns not yet developed; 2) Maturing: flexible claspers with length longer than the pelvic fin, sperm ducts beginning to coil, developing alar thorns; and 3) Mature: rigid claspers fully calcified, total or partially coiled sperm ducts, developed alar thorns.

For the females, three maturity stages were considered: 1) Immature: granulated ovaries with undifferentiated follicles, thread-like uteri attached to the dorsal wall of the body cavity, undifferentiated nidamental glands; 2) Maturing: enlarged ovaries, white follicles of several sizes beginning to differentiate, straight and enlarging uteri and nidamental gland in development; and 3) Mature yellow vitellogenic ovarian follicles, wide pendulous uteri, with or without egg capsules, heart-shaped nidamental glands.

For both sexes, the percentage of mature individuals by length classes of $1.0 \mathrm{~cm}$ was calculated. For the estimation of size-at-maturity, i.e., size at which $50 \%$ of the skate sample was mature $\left(\mathrm{L}_{\mathrm{T} 50}\right)$, a logistic model was adjusted to the binomial set of data (immature $=0$, mature $=1$ ) as: $y=\left[1+e^{(a+b x)}\right]^{-1}$ where $\mathrm{y}$ is the percentage of mature individuals and $\mathrm{x}$ the TL class, with $a$ and $b$ being the model's parameters. Using this equation, median maturity TL is given by a/b (Mollet et al., 2000).

Description of the egg capsule. In order to provide a description of the egg capsule of $D$. chilensis, a pair of term capsules was collected in uteri. Description terminology followed Hubbs and Ishiyama (1968). Variables recorded were: length without horns, anterior horns' length, width, height, thickness and lateral keel width ( $\mathrm{mm}$ ) and weight (g). All measurements were made with $0.1 \mathrm{~mm}$ precision calipers. Coloration 
and surface microscopic configuration of the egg capsule wall were also recorded.

\section{Results}

Size composition of the catch. A total of 3518 (1607 males and 1911 females) individuals were sampled. Female and male TL range and statistics are presented in Table 1 . Males ranged from 44 to $99 \mathrm{~cm}$ and females from 45 to $110 \mathrm{~cm}$. Total length composition of the grouped catches differed significantly between sexes ( $U=1244469$, $p<0.05)$, with the females being

Table 1. Total number (TN) and percentage (\%) of specimens of Dipturus chilensis determined along with the standard deviation (SD, in parentheses), total length range (TL range, $\mathrm{cm}$ ), mean total length (Mean TL, along with the standard deviation), CV (coefficient of variation) and number $(\mathrm{N})$ and percentage (\%) of individuals assessed for reproduction analysis by maturity stage (immature $=\mathrm{I}$; mature $=\mathrm{M}$ ) and sex; total length range (TL range) by sex; observed length-atmaturity (OLM) and size at which $50 \%$ of the individuals were sexually mature $\left(T_{L 50}\right)$.

\begin{tabular}{ll}
\hline TN (\%) males & $1607(45.7)$ \\
TL range males & $44-99$ \\
Mean TL ( \pm SD) males & $69.8 \pm 11.1$ \\
CV & 9.1 \\
TN (\%) females & $1911(54.3)$ \\
TL range females & $45-110$ \\
Mean TL ( \pm SD) females & $74.0 \pm 12.8$ \\
CV & 7.8 \\
No. (\%) I males & $39(81.3)$ \\
TL range I males & $56-78$ \\
N (\%) M males & $9(18.8)$ \\
TL range M males & $79-98$ \\
OLM males & 79 \\
TL 50 males & 78.5 \\
N (\%) I females & $62(81.6)$ \\
TL range I females & $45-90$ \\
N (\%) M females & $14(18.4)$ \\
TL range M females & $74-100$ \\
OLM females & 74 \\
TL & 81.4 \\
\hline
\end{tabular}

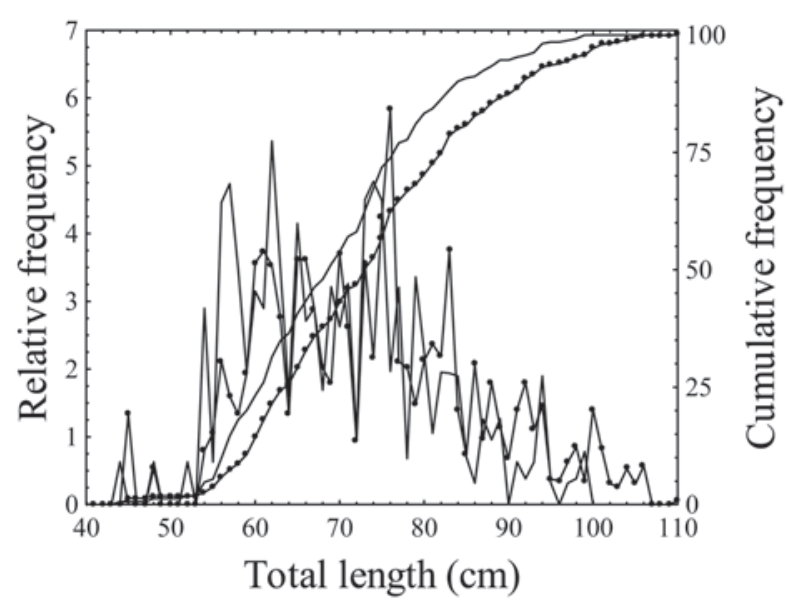

Fig. 2. Relative and cumulative frequency of total length for Dipturus chilensis by sex (males=continuous line; females=line with circles). larger than males. The resulting overall sex ratio was significantly different from $1: 1(\mathrm{p}<0.05)$, favoring the females. The $\mathrm{TL}$ at which $50 \%$ of the specimens were retained by the gear was $69 \mathrm{~cm}$ for the males and $73 \mathrm{~cm}$ for the females (Fig. 2).

Maturity estimates. A total number of 124 specimens was recorded (48 males, 76 females). Males ranged from 56 to 98 $\mathrm{cm}$ of TL. Of the total male sample, $81 \%$ were immature and $19 \%$ mature. The smallest mature male captured was $79 \mathrm{~cm}$, whereas the largest immature one was $78.0 \mathrm{~cm}$ of TL.

In Figure 3, it can be observed that from TL of $79.0 \mathrm{~cm}$ onward, all the specimens were mature, and claspers grew continuously in relation to TL.

Females ranged from 45 to $100 \mathrm{~cm}$ of TL, with a percentage of $82 \%$ immature and $18 \%$ mature specimens. The smallest mature female captured was $74 \mathrm{~cm}$ of TL, while the largest immature was $90 \mathrm{~cm}$ long. Observed TL range as well as number of individuals per maturity stage by sex is presented in Table 1.

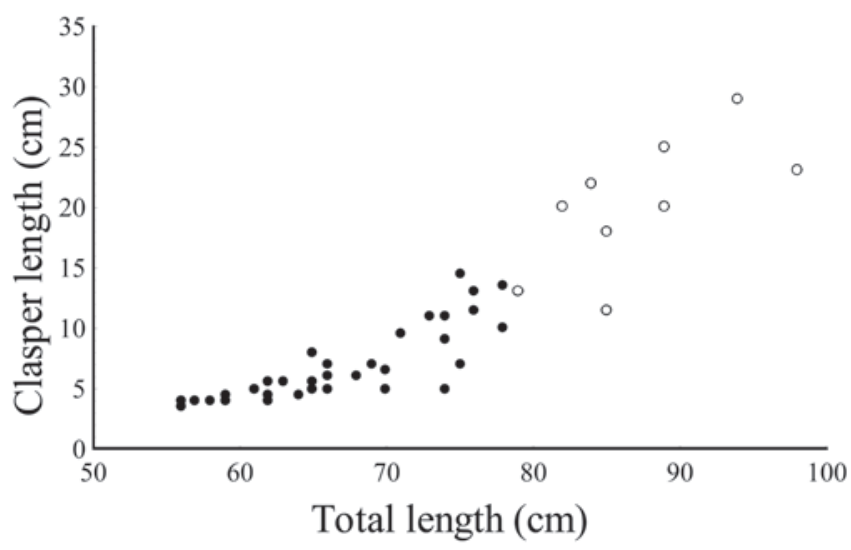

Fig. 3. Relationship between total length $(\mathrm{cm})$ and clasper length $(\mathrm{cm})$ for Dipturus chilensis (immature=filled circles; mature $=$ open circles).

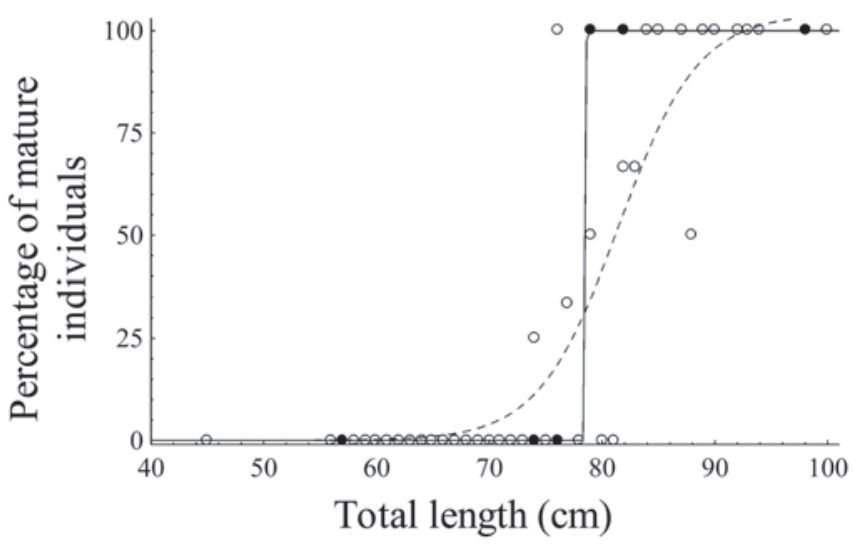

Fig. 4. Percentage of mature males and females of Dipturus chilensis by total length class of $1.0 \mathrm{~cm}$. Line represents the logistic model adjusted (solid line, filled circles $=$ males, dotted line,open circles =females). 
For the males, $\mathrm{L}_{\mathrm{T} 50}$ was estimated at $78.5 \mathrm{~cm}(\mathrm{r}=1, \mathrm{n}=48)$ (Fig. 4), corresponding to $80 \%$ of the maximum observed TL $(98.0 \mathrm{~cm})$. For the females, this parameter was estimated at $81.4 \mathrm{~cm}$ of TL ( $r=0.88, \mathrm{n}=76$ ) (Fig. 4), representing $81 \%$ of the maximum observed TL $(100.0 \mathrm{~cm})$.

Description of the egg capsule. A single egg-bearing female was caught, with one term egg capsule per oviduct. Coloration of the term egg capsules was golden yellow with a greenolive shine. Egg capsule length was $136 \mathrm{~mm}$. Dorsal and ventral surfaces were longitudinally striated with flat and laterally grooved edges. The dorsal capsule wall was convex;

Table 2. Measurements (mm) recorded for a pair of egg capsules of Dipturus chilensis; length without horns; anterior horns' length; capsule width and height, thickness and width of the lateral keel and capsule weight (g). Total length range of the egg-bearing female from which the pair of egg capsules was extracted (TL ) is indicated.

\begin{tabular}{lll}
\hline TL egg-bearing female & 92 & \\
\hline capsule & Right & left \\
length without horns & 133 & 136 \\
anterior horns length & $54-47$ & incomplete - 48 \\
width & 75 & 72 \\
Height & 24 & 27 \\
thickness lateral keel & 3 & 2 \\
width lateral keel & 5 & 4 \\
Weight & 61.26 & 75.05 \\
\hline
\end{tabular}

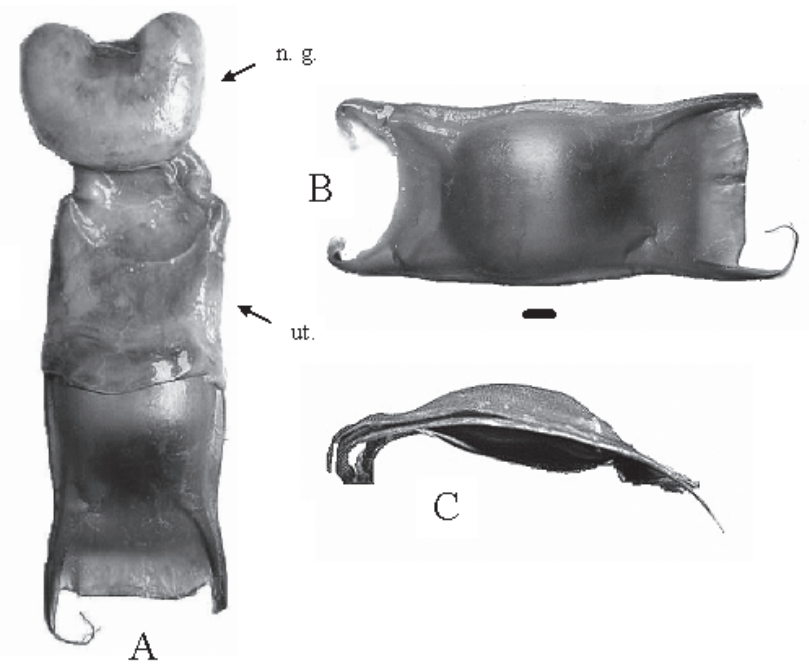

Fig. 5. (A) A fresh single posterior (left) oviduct of $92.0 \mathrm{~cm}$ female of Dipturus chilensis; n. g.=nidamental gland; ut.=uterus (posterior end, toward the nidamental gland). (B) The term egg capsule of Dipturus chilensis in upper view (same capsule as in A). (C) Lateral view of a fixed egg capsule of Dipturus chilensis (same capsule as in A and B). Black bar represents $1 \mathrm{~cm}$ in B and C. In B and C, anterior end to the left and posterior end to the right. while the ventral was rather flat. Posterior horns length was about the egg capsule length and two times the anterior horns' length, becoming filamentous towards the tips and curving inwards. Egg capsule surface texture was smooth to the touch. The posterior velum was $4 \mathrm{~cm}$ long and slightly convex. The anterior velum had a length of $1.7 \mathrm{~cm}$, being concave (Fig. 5). Measurements are presented in Table 2.

\section{Discussion}

In the present work, the maturity estimates for both sexes reflected a clear diminution of size-at-maturity in the area, when compared to the previous estimate by Oddone et al. (2005) for the period of 1994-1995. This previous study indicated size-at-maturity of 85 and $104 \mathrm{~cm}$ of TL for males and females, respectively. Also, if compared with the finding of Leible (1987) of $85 \mathrm{~cm}$ for the males and that of Fuentealba \& Leible (1990) of $100 \mathrm{~cm}$ for females, the differences are striking, though they were calculated for the Pacific.

Dipturus chilensis represents the major proportion of bycatch in bony fish target of fisheries of the bottom trawling commercial fleet operating off Uruguay, followed by the softnose skates Bathyraja brachyurops and B. macloviana. Moreover, two longline fishery vessels directed at $D$. chilensis already exists (also targeting the smallnose fanskate Sympterygia bonapartii) and their "wings" (pectoral fins) area exported to Asia, namely to Korea.

According to Licandeo et al. (2006), D. chilensis could not stand intense exploitation because of it life-history traits, and moreover, the species identification problems that led to misidentifying $D$. chilensis as the congeneric $D$. trachyderma (the latter attaining much larger sizes) could have important consequences for fishery management, given that changes in the life-history parameters cannot be easily detected, as suggested by Jennings et al. (1998).

Agnew et al. (2000), studying the Falkland Islands multispecific fisheries, noted that $D$. chilensis was the species that showed the most consistent reduction in its mean length and observed maximum length during a short fishing period. Licandeo et al. (2006), in agreement with Dulvy et al. (2000), argued that species that attain larger lengths and mature later are substituted by smaller species that mature earlier when subjected to high fishing mortality. Moreover, Dulvy et al. (2000) proposed that species that attained larger size were less resilient to overexploitation, because late maturity leads to low population increment rates. In the same way, Brander (1981) had already demonstrated that not all species are equally sensitive to fishery impact, and that those with smaller size-at-maturity would be more resilient.

In view of the aforementioned, it can be concluded that fisheries have affected the size-at-maturity of $D$. chilensis in the area in question. Such reduction in size-at-maturity due 
to fisheries has already been reported for fishes (Walters \& Martell, 2004), and it is known to have affected several elasmobranch species (Brander, 1981; Casey \& Myers, 1998). According to Fogarty et al., 1989 (apud Walker \& Ellis, 1998), the negative effect of exploitation may be counteracted by compensatory mechanisms such as density- dependent changes in fecundity, age or size at maturation. Differences in size-at-maturity for a given species may also be related to other reasons such as the area to which the species belongs. Templeman (1987), for instance, noted that sexual maturity of the thorny skate Raja radiata occurred at relatively small sizes off northern Iceland and West Greenland, off Baffin Island and Labrador, on the Northeast Newfoundland Shelf and in the Gulf of St. Lawrence, and at considerably larger sizes on the Grand Bank and St. Pierre Bank. Mabragaña \& Cousseau (2004) noted latitudinal variations in the size frequency, maximum length and maturity for Psammobatis rudis and $P$. normani, arguing that this could be a consequence of oceanographic conditions and the effect of fishing pressure. For Rioraja agassizi, endemic to the SW Atlantic, Colonello et al. (2007) estimated size-at- maturity for the area situated between southern Brazil and northern Argentina, at $47 \mathrm{~cm}$ for males and $52 \mathrm{~cm}$ for females, whereas Oddone et al. (2007) reported contrasting values of 32 and $40 \mathrm{~cm}$, respectively, for southeastern Brazil.

With regard to the sexual development of the males, unlike what is commonly observed in elasmobranch males (claspers do not continue growing in length during the mature stage), the clasper growth in mature $D$. chilensis showed a continuous growth pattern. Such pattern was also observed in $A$. castelnaui and A. platana (Oddone \& Amorim, 2008; Oddone et al., 2008a).

The size composition patterns significantly differed between sexes. However, before making definitive conclusions, it must be considered that the analyses of length distribution in fishery-dependent samples of skates may be biased, due to gear selectivity or to selective retention of larger more commercially valuable specimens (Matta \& Gunderson, 2007).

On the other hand, the skewed distribution of TL due to bias did not interfere in the calculation of size-at-maturity, because only immature individuals were missing in the samples. Intrinsic gear characteristics (mesh size for instance) may be related to this kind of results. In samples coming from the commercial bottom trawl fleet operating in southeastern Brazil, an incidence of young and even neonate specimens of Atlantoraja spp. and R. agassizi was noted (Oddone, unpublished data). This fact, also observed for other skate species (Braccini \& Chiaramonte, 2002), may have important implications for the management of skates, because fishing mortality in the young could be avoided should management decisions be taken. The differences observed in the sex ratio in the catch's composition could be a reflection of segregation in sexes, size and/or maturity stage (Ebert, 2005) or also due to extrinsic factors such as depth and latitudinal distribution, season and temperature shifts (Compagno et al., 1991).

Length at which $50 \%$ of the individuals were retained by the gear, was smaller than the size at first maturity. Similar results were obtained for $D$. chilensis and A. castelnaui (Oddone et al., 2005; 2008a). This is a matter of concern regarding the conservation of these species, because given that both species are retained before attaining maturity, specimens that are subjected to fishery will not be able to mature and reproduce.

As observed by Holden (1974), Walker \& Hislop (1998), Dulvy et al. (2000), Francis et al. (2001), Oddone \& Vooren (2005) and Ebert (2005), the onset of maturity in males and females of $D$. chilensis occurs when specimens have attained maturity at $80 \%$ of their maximum observed TL, indicating that in this species a prolonged immature stage occurs, followed by a rather short adolescent phase, prior to sexual maturity. This pattern was also observed for A. castelnaui and A. platana, where males and females were found to mature at $83 \%$ and $91 \%$ and $89 \%$ and $94 \%$ of their observed maximum sizes (Oddone \& Amorim, 2008; Oddone et al., 2008a).

The $\mathrm{L}_{\mathrm{T} 50}$ was approximately the same in both sexes (78.5 and $81.4 \mathrm{~cm}$ for males and females, respectively). Oviparous elasmobranchs (in contrast to viviparous, which commonly have females maturing at larger sizes than males), may have requirements (either physiological or anatomical) that lead to this kind of observation (Ebert, 2005). Matta \& Gunderson (2007) reported similar values of $\mathrm{L}_{\mathrm{T} 50}$ for $B$. parmifera, indicating that females attain maturity at slightly larger sizes than males. However skate genera such as Atlantoraja and Rioraja are endemic to the Southwestern Atlantic Ocean (McEachran \& Aschliman, 2004), and have demonstrated to be strongly sexually dimorphic with regard to size-at-maturity (Oddone \& Vooren, 2005; Oddone \& Amorim, 2008; Oddone et al., 2008a).

The estimate of $\mathrm{L}_{\mathrm{T} 50}$ for males was lower than the size of the smallest mature individual observed. However, this difference was small and, according to Ebert (2005) who also noted this fact for several Bathyraja species, may be related to small sample size and the consequent lack or small number of replicates of individuals within the same size class. This resulted in fits to binomial maturity data that produced values of $\mathrm{L}_{\mathrm{T} 50}$ lower than the size of the smallest mature individual observed. Likely, the estimate of $\mathrm{L}_{\mathrm{T} 50}$ obtained with larger sample sizes could better reflect the $\mathrm{L}_{\mathrm{T} 50}$ of the population, and smaller mature individuals would be found, which could result in a smaller value of $\mathrm{L}_{\mathrm{T} 50}$ (Ebert, 2005). It is therefore important to keep in mind that size-at-maturity is an observed value and $\mathrm{L}_{\mathrm{T} 50}$ is a theoretical value.

On the other hand, Braccini \& Chiaramonte (2002), work- 
ing with larger sample sizes, noted that in $P$. extenta the onset of maturity occurs at only 1 and $1.3 \mathrm{~cm}$ (males and females, respectively) below the estimated $\mathrm{L}_{\mathrm{T} 50 \text {. }}$.

The fact that rajids are closely related from an ecological point of view, makes it virtually impossible to direct the fisheries to just a single species (Agnew et al., 2000). Fishermen declare their "ray" catch as a mixed species total (in some cases of both rajids and myliobatiforms), as a result of the lack of commercial incentive to separate the specimens to a species-specific level. Thus, the identification of species on board would be crucial for assessing both the real size of the catches and their development, and the composition of sizes.

Dipturus species may be particularly vulnerable to fishery pressure because of their large size. Dulvy \& Reynolds (2002) observed that the skate species that have disappeared from substantial parts of their ranges ("locally extinct") had large body sizes when compared with all other skates. The disappearance of $D$. batis and $D$. laevis is to date well known (Brander, 1981; Casey \& Myers, 1998). The unknown present status of $D$. chilensis is therefore a matter of concern and it is recommended that their populations in the area of occurrence be assessed, in order to establish conservation measures and make decisions.

So far, there are no bibliographic references on the egg capsule of $D$. chilensis. Statistical evaluation was not possible in the present work because just a single pair of capsules was recorded. For the area in question, egg capsules of $D$. chilensis are likely to be the largest ones along with $D$. trachyderma capsules, which also remain undescribed to date, but are known to attain a mean length of $13 \mathrm{~cm}$ (F. Concha, pers. com.) as with $D$. chilensis. Smooth egg capsule surfaces have also been noted in Atlantoraja castelnaui, Rioraja agassizi and also for Sympterygia acuta and S. bonapartii (Oddone \& Vooren, 2002; Oddone et al., 2006; 2008b). Given that the egg capsule serves essentially for the protection of the egg during the development in sea water, they could have undergone successive changes in their characteristics in order to adapt to their environment (Ishiyama, 1958). According to the latter cited author, the capsules of the species that have to withstand long incubation periods in sea water (occurring in deeper areas), developed more sophisticated configurations of the capsule surfaces, which would protect the egg mechanically from natural dangers and predators during such period of incubation. The egg capsules of A. platana and $A$. cyclophora, for instance, have striated surfaces that make them rough to the touch and microscopically markedly corrugated (Oddone et al., 2004; Oddone, 2005). In southern Brazil, specimens of $A$. cyclophora and A. platana are found at depths of up to $300 \mathrm{~m}$ and temperatures ranging between $10.0^{\circ} \mathrm{C}$ and $17.6^{\circ} \mathrm{C}$ (Vooren, 1997; Oddone \& Vooren, 2004). The smooth surface of the egg capsules of $D$. chilensis, could be related to the depth at which this species occurs in the area in question (50 to $398 \mathrm{~m}$, Paesch, pers. obs.) and therefore to a shorter incubation period. Further data are needed to confirm this hypothesis.

\section{Acknowledgments}

Special thanks go to Elizabeth Delfino for collaborating in the skate sampling in the field, to Pablo Meneses for aiding in the sampling and processing of the egg capsules and to Dr. Walter Norbis for critically reading the draft manuscript and making valuable suggestions. A. Leyva provided English editing of the manuscript.

\section{Literature cited}

Agnew, D. J., C. P. Nolan, J. R. Beddington \& R. Baranowski. 2000. Approaches to the assessment and management of multispecies skate and ray fisheries using the Falklands Islands fishery as an example. Canadian Journal of Fisheries of Aquatic Sciences, 57: 429-440.

Braccini, J. M. \& G. E., Chiaramonte. 2002. Reproductive biology of Psammobatis extenta. Journal of Fish Biology, 61: 272-288.

Brander, K. 1981. Disappearance of common skate Raia batis from Irish Sea. Nature, 290: 48-49.

Caddy, J. F. \& R. Mahon. 1996. Puntos de referencia para la ordenación pesquera. FAO Documento Técnico de Pesca, 347, 109p.

Casey, J. M. \& R. A. Myers. 1998. Near extinction of a large, widely distributed fish. Science, 281: 690-691

Colonello, J. H., M. L. García \& C. A. Lasta. 2007. Reproductive biology of Rioraja agassizi from the coastal southwestern Atlantic ecosystem between northern Uruguay $\left(34^{\circ} \mathrm{S}\right)$ and northern Argentina $\left(42^{\circ} \mathrm{S}\right)$. Environmental Biology of Fishes, Special Issue Skates: DOI 10.1007/s10641-007-9239-0

Compagno, L. J. V. 1984. Sharks of the world. FAO Fisheries Synopsis 125/4, $665 \mathrm{pp}$

Compagno, L. J. V. 2005. Checklist of living Chondrichthyes. p 503-548. In: Hamlett, W. C. (Ed.). Reproductive biology and phylogeny of chondrichthyes, Sharks, batoids and chimaeras. Science Publishers, Inc. Enfield (NH), USA.

Compagno, L. J. V., D.A. Ebert \& P. D. Cowley. 1991. Distribution of offshore demersal cartilaginous fish (Class Chondrichthyes) off the west coast of Southern Africa, with notes on their systematic. South African Journal of Marine Science, 11: 43-139.

Dulvy, N. K., J. D. Metcalfe, J. Glanville, M. G. Pawson \& J. D. Reynolds. 2000. Fishery stability, local extinctions, and shifts in community structure in skates. Conservation Biology, 14: 283-293.

Dulvy, N. K. \& J. D. Reynolds. 2002. Predicting extinction vulnerability in skates. Conservation Biology, 16: 440-450.

Ebert, D. A. 2005. Reproductive biology of skates, Bathyraja (Ishyama), along the eastern Bering Sea continental slope. Journal of Fish Biology, 66: 618-649.

Francis M. P., C. O. Maolagain \& D. Stevens. 2001. Age, growth and sexual maturity of two New Zealand endemic skates Dipturus nasatus and D. innominatus. New Zealand Journal and Marine and Freshwater Research, 35: 831-842. 
Frisk, M. G., T. J. Miller \& M. J. Fogarty. 2002. The population dynamics of little skate Leucoraja erinacea, winter skate Leucoraja ocellata, and barndoor skate Dipturus laevis: predicting exploitation limits using matrix analyses. ICES Journal of Marine Science, 59: 576-586.

Fuentealba, M. \& M. D. Leible. 1990. Perspectivas de la pesquería de la raya volantín Raja (Dipturus) flavirostris: Estudio de edad, crecimiento y algunos aspectos reproductivos. Pp. 227-236. In: Barbieri, M. A. (ed.). Perspectivas de la actividad pesquera en Chile. Escuela de Ciencias del Mar, Universidad Católica de Valparaíso.

Hoenig, J. M. \& S. Gruber. 1990. Life-History Patterns in the Elasmobranchs: Implications for Fisheries Management. NOAA Technical Report, NMFS- 90: 1-16.

Holden, M. J. 1974. Problems in the rational exploitation of elasmobranch populations and some suggested solutions. Pp 117-130. In: Harden-Jones, F.R. (Ed.) Sea Fisheries Research. Logos Press, London.

Hubbs, C. I. \& R. Ishyama. 1968. Methods for the taxonomic studies and description of skates (Rajidae). Copeia, 1968: 483-491.

Ishiyama, R. 1958. Observations on the egg-capsules of skates of the family Rajidae, found in Japan and its adjacent waters. Bulletin of the Museum of Comparative Zoology at Harvard College, 118/1: 1-24.

Jennings, S., J. D. Reynolds \& S. C. Millis.1998. Life history correlates of responses to fisheries exploitation. Proceeding of the Royal Society of London, 265:333-339.

Leible, D. M. 1987. La pesquería de rayas en Chile. Problemática y potencialidad. Pp. 69-80. In: Arana, P. (Ed.). Manejo y Desarrollo Pesquero. Escuela de Ciencias del Mar, Universidad Católica de Valparaíso.

Licandeo, R. R., J. G. Lamilla, P. G. Rubilar \& R. M. Vega. 2006. Age, growth, and sexual maturity of the yellownose skate Dipturus chilensis in the south-eastern Pacific. Journal of Fish Biology, 68: 488-506.

Lucifora, L. O., J. L. Valero, C. S. Bremec \& M. Lasta. 2000. Feeding habits and prey selection by the skate Dipturus chilensis (Elasmobranchii: Rajidae) from the south-western Atlantic. Journal of the Marine Biological Association of the United Kingdom 80(5): 953-954.

Lucifora, L., J. L. Valero \& V. B. García. 1999. Length at maturity of the greeneye spurdog shark, Squalus mitsukurii (Elasmobranchii: Squalidae), from the SW Atlantic, with comparisons with other regions. Marine and Freshwater Research, 50: 629-632.

Mabragaña, E. \& M. B. Cousseau. 2004. Reproductive biology of two sympatric skates in the south-west Atlantic: Psammobatis rudis and Psammobatis normani. Journal of Fish Biology, 65: 559-573.

Matta, M. E. \& D. R. Gunderson. 2007. Age, growth, maturity, and mortality of the Alaska skate Bathyraja parmifera, in the eastern Bering Sea. Environmental Biology of Fishes, Special IssueSkates, DOI 10.1007/s10641-007-9223-8.

McEachran, J. D. \& N. Aschliman. 2004. Phylogeny of Batoidea. Pp 79-113. In: Carrier, J. C., J. A. Musick \& M. R. Heithaus (Eds.). Biology of sharks and their relatives. Press, London, 596 pp.

Menni, R. C. \& A. E. Gosztonyi. 1982. Benthic and semidemersal fish associations in the Argentine Sea. Studies on Neotropical Fauna and Environment, 17: 1-29.

Menni, R. C. \& H. L. López. 1984. Distributional patterns of
Argentine Marine fishes. Physis, 42: 71-85,

Mollet, H. F., G. Cliff, H. L. Pratt Jr. \& J. Stevens. 2000. Reproductive biology of the female shortfin mako, Isurus oxyrinchus Rafinesque, 1819, with comments on the embryonic development of lamnoids. Fishery Bulletin US, 98: 299-318.

Oddone, M. C. 2005. The microscopic structure of the egg capsules of Atlantoraja cyclophora (Elasmobranchii: Rajidae: Arhynchobatinae). Biota Neotropica 5: 1-4.

Oddone, M. C \& A. F. Amorim. 2008. Size at maturity of Atlantoraja platana (Günther, 1880) (Chondrichthyes: Rajidae: Arhynchobatinae) in the SW Atlantic Ocean. Journal of Fish Biology, 72, 1515-1519.

Oddone, M. C., A. F. Amorim, P. L. Mancini, W. Norbis \& G. Velasco. 2007. The reproductive biology and cycle of Rioraja agassizi (Müller and Henle, 1841) (Chondrichthyes, Rajidae), in southeast Brazil, SW Atlantic Ocean. Scientia Marina, 71(3): 593-604.

Oddone, M. C, P. L. Mancini \& A. F. Amorim. 2008a. (in press). The reproductive biology of the spotback skate, Atlantoraja castelnaui (Chondrichthyes, Rajidae) in southeastern Brazilian waters. Revista de Biologia Marina y Oceanografia.

Oddone, M. C., A. S. Marçal \& C. M. Vooren. 2004. Egg capsules of Atlantoraja cyclophora (Regan, 1903) and A. platana (Günther, 1880) (Pisces, Elasmobranchii, Rajidae). Zootaxa, 426: $1-4$.

Oddone, M. C., A. Mesa \& A. F. Amorim. 2006. The egg capsule of Rioraja agassizi (Müller \& Henle, 1841) (Elasmobranchii, Rajidae), endemic to the SW Atlantic. Pan-American Journal of Aquatic Sciences, 1(2): 43-48.

Oddone, M. C., A. Mesa \& A. F. Amorim. 2008b. Description of the egg capsule of Atlantoraja castelnaui (Elasmobranchii, Rajidae). Brazilian Journal of Oceanography, 56(1): 65-68.

Oddone, M. C., L. Paesch \& W. Norbis. 2005. Length at first sexual maturity of two species of rajoid skates, genera Atlantoraja and Dipturus (Pisces, Elasmobranchii, Rajidae), from the Southwestern Atlantic Ocean. Journal of Applied Ichthyology, 21: $70-72$.

Oddone, M. C. \& C. M.Vooren. 2004. Distribution and abundance of Atlantoraja cyclophora (Regan 1903) (Elasmobranchii, Rajidae) with regard to salinity, temperature and depth in southern Brazil, south-western Atlantic. Neotropical Ichthyology, 2: 137-144.

Oddone, M. C. \& C. M. Vooren. 2005. Reproductive biology of Atlantoraja cyclophora (Regan 1903) (Elasmobranchii, Rajidae) off southern Brazil. ICES Journal of Marine Science, 62: 10951103.

Sokal, R. R. \& F. J. Rohlf. 1998. Biometry: the principles and practice of statistics in biological research. Ed by W.H. Freeman and Company, New York. 850 pp.

Templeman, W. 1987. Differences in sexual maturity and related characteristics between populations of thorny skate (Raja radiata) from the Northwest Atlantic. Journal of Northwest Atlantic Fisheries Science, 7: 155-167.

Vooren, C. M. V. 1997. Demersal elasmobranch. Pp. 141-147. In: Seeliger, U., C. Odebrecht \& J. P. Castello (Eds). Subtropical convergence environments: the coast and sea in the southwestern Atlantic.

Walker, P. A. \& J. Ellis. 1998. Ecology of rays of the north-eastern Atlantic. Pp 7-29 In: Biology of Skates. Proceedings of the Biology of Skates Symposium (New Orleans, 1996). Princeton Press 
Walker, P. A. \& H. J. L. Heessen. 1996. Long-term changes in ray population in the North Sea. ICES Journal of Marine Science, 53: 1085-1093.

Walker, P. A. \& J. R. G. Hislop. 1998. Sensitive skates or resilient rays? Spatial and temporal shifts in ray species composition in the central and north-western North Sea between 1930 and the present day. ICES Journal of Marine Science, 55: 392-402.

Walters, C. J. \& S. J. D. Martell. 2004. Chapter 3. Strategic requirements for sustainable fisheries. Pp. 43-64. In: Walters, C. J. \& S. J. D. Martell (Eds.) Fisheries Ecology and Management. Princeton Univ. Press, Princeton, NJ.

Accepted May 2008 Published June 28, 2008 